CIRR XXIII (77) 2017, 81-715

ISSN 1848-5782

UDC 323:338/496.5)

DOI 10.1515/cirr-2017-0003

\title{
Albania's Transformation since 1997: Successes and Failures
}

Islam Jusufi

\section{Abstract}

In 1997 Albania experienced a collapse of order and widespread violence, which resulted in a situation where the government was overthrown and some 2,000 people were killed. The 1997 disorder came as a result of the collapse of fraudulent financial pyramid schemes that had all the features of a war-like economic structure. During the 1997 events, large-scale confiscation and stealing of state assets occurred. Albania's transitional period from communism to democracy, which began in 1990, led to the establishment of new structures for profiting from the country's resources. Some of these political and economic structures, in the aftermath of the 1997 events, disappeared and others, including their structural effects, persist and have had an impact on the country's political stability and economic progress. Today, both the successes and failures of the country are assessed based on the progress that the country has made since the 1997 events. The paper analyses the 1997 events and the transformation of Albania's political and economic structures between 1997 and 2016, considering both achievements and failures. It looks at how the country has dealt with the post-1997 peace-building and development agenda from the perspective of it being a success. It looks at the factors that led to state failure in 1997 and at the factors that continue and have generated a path dependency to the current political context of the country. Although a lot has been written concerning the 1997 events, very little analysis has been conducted concerning what it means from the perspective of research on state failure. In this context, the proposed paper seeks to offer Albania as a case study example of a transformation process, from the uprising to the current situation, which is characterized as a mixture of successes and failures. The belief is that the proposed paper will point to some lessons learned for the strategies directed at the transformation processes. 
In 1997 law and order collapsed in Albania. The country survived the Balkan wars of the 1990s that led to human carnage in Bosnia, Kosovo and elsewhere. However, it fell prone to civil disorder in 1997. The disorder of 1997 was the second collapse of the state of Albania in less than a decade, in this small European country that seven years earlier, in 19901992, underwent systemic change, going from being communist and in a state of dictatorial isolation to being a pluralistic democracy with a free market economy. The armed insurgency of the spring of 1997 is one of the most dramatic historical events that Albania faced (Vickers and Pettifer 2007). The political and economic goals set in 1990-1992 for this impoverished society, which had lived most of its post-Second World War years in self-imposed total isolation (Backer 1982), were overambitious. The Albanian state of the early 1990s, which no longer had the centrally controlled order of communism and which had all the weak state features of a post-communist society, descended into a disillusioned transition process that was certain to collapse - and so it did in less than a decade. The catalyst and trigger of the collapse were the country's war-like economic structures, such as the pyramid schemes that emerged during this period, which benefited from the uncontrolled and ungoverned order. The pyramid schemes were only the catalyst of what was to come in 1997; the real reasons for the 1997 collapse can be sought in other areas, including the overall politico-economic governance of Albania in the early 1990s, which had features of weak economic and political governance. It is this specific governance type that brought about the collapse of 1997. The disorder that occurred had all the features of a state failing and distinct features that require a thorough review of the situation in 1997. Also, the transformation seen in the country since 1997 has been remarkable. Thus, it necessitates the need to re-construct the meaning of the 1997 disorder, which after all did not have a wholly negative impact on the country's future. Apparently, the disorder and riots of 1997 came to represent a benchmark for the country in its path to political and economic modernization.

In the aftermath of 1997, despite some temporary economic and political crises, the country went through a substantial political and economic 
transformation, during which some of the old political and economic characteristics that are distinct to the country-such as political clientelism, cleavage and polarization - began to retreat. The number of economic structures closely resembling war-type economies receded after the end of the 1997 events. Nevertheless, a number of other political and economic structures persist and continue to exercise a certain kind of path dependency to the country's political and economic transformation.

As a Balkan country of around 2.9 million people (INSTAT 2016), Albania has great potential for peace and order and rapid economic growth, as it has not had the ethnic problems that have confronted other Balkan countries and is endowed with geographic importance and natural mineral resources (Yusufi et al. 2012). Its natural resources include significant hydropower potential and an Adriatic and loanian coastline with tourism and transport potential (World Bank 2015). Albania is also a nation that is growing in economic and political importance internationally, with NATO membership and as a candidate for EU membership. Its young and educated population, although it suffers from a low fertility and high emigration rate, adds to its human potential.

Yusufi et al. (2012) argued,

The collapse of communism in 1990 gave the opportunity for the country to gain a hard won freedom. It was the only Balkan country to avoid civil war following the fall of communism. The historical change of 1990, however, did not immediately offer new prospects for progress. Instead, a very difficult period followed, in both the economic and political arenas that resulted in a long period of transition. (Yusufi et al. 2012: 5)

Albania's first phase of transition ended in 1997, when the country was on the brink of civil war with civil unrest spreading to all parts of the country. The 1997 unrest, the catalyst of which was the collapse of the pyramid schemes, hit the country hard, creating a security vacuum and leading to anarchy and political and economic collapse, with all the elements that made it become a rogue state (International Crisis Group 1999) or a case of state failure in Europe. 
The two main research questions of the paper are why the transitional political and economic order of Albania gave way to the collapse of 1997 and what kind of an impact the 1997 collapse had on the subsequent transformation of Albania. Other related questions considered include the following: What were the characteristics of the civil disorder of 1997 , which came to be an important event in Albania's post-communist history, probably as important as that of the collapse of the dictatorship in 1990? What political and economic structures for profiting from the country's disorder existed? How were these structures affected by the 1997 disorder? What new structures were established in 1997? Did these structures disappear or did they survive the post-1997 transformation of Albania? How has the country progressed or failed in light of the 1997 events? What lessons does Albania's transformation provide? Today, both the successes and failures of Albania are mostly assessed based on the progress that the country has made after 1997.

This paper seeks to analyse the disorder Albania experienced in 1997 as a case that can shed light on state disorder in international relations and the transformation of conflict societies. It looks at how the 1997 events happened and how they led to state collapse. The paper seeks to relate the disorder seen in Albania in 1997 to research on state disorder in political science and international relations. It looks at how this disorder was tackled. With this, the aim is to analyse whether the experience of state disorder has an influence in terms of overcoming the legacies of the past, whether it institutionalizes old/new structures that hinder a country's economic growth and political development or whether it has the power to transform the society for the better.

The paper finds that the civil disorder led to a quick recovery and had a transformational impact on Albania's politics, security, economics and development. The country was able to quickly, in a matter of less than a year or two, overcome the disorder and establish a progressive path for its transformation, overcoming the legacies of the early 1990s and the implications of the 1997 disorder. It avoided becoming trapped in a state of perpetual disorder, as seen in other cases of state failure in different parts of the world. The 1997 events and aftermath caused some of the older structures and some of the structures that were directly related to the 1997 events to disappear. The 1997 events also helped to 
pave the way for overcoming the existing political clientelism, cleavages and polarization. Nevertheless, it also led to the establishment of new structures for profiting from the country's politico-economic governance, which have survived to date and that stand as path dependent factors in Albania's current political and economic transformation. Their structural effects continue to have an impact on the country's political stability and economic progress.

This paper provides a framework for analysing two questions: how the country became engulfed in a state of disorder and how it was transformed. It is important to know what determined the outcome of the 1997 events. Albania escaped the fate of Yugoslavia. However, it was still engulfed in disorder, culminating in the 1997 events. It made democratic gains; however, it was not able to consolidate mass democracy, leading to the reversal in 1997, but it was also to quickly recover in the aftermath.

Notwithstanding the merits of generalizations based on models of state disorder, as Gerxhani and Schram state, "careful analysis of specific institutions can help us understand real world phenomena in greater depth" (Gerxhani and Schram 2000b: 3). This paper is an attempt to provide such an assessment, and it studies the political disorder that was observed in Albania in 1997. What happened in 1997 when anarchy ruled the country included specific aspects of political disorder that make the 1997 case of Albania a great candidate for better understanding cases of state failure around the world. Rather than collecting data on many countries, as is commonly done in research on state failure or disorder, this paper limits the research to a specific country case study analysis. This is done in part because Albania provides a rare case study opportunity to explore state failure and political disorder. The paper also does so because its author finds it necessary to draw upon his own observations.

Although a lot has been written on Albania's post-communist transformation, very little analysis has been conducted on what happened in 1997 and how it relates to the transformation of civil unrest or state disorder. The proposed paper seeks to analyse the 1997 disorder, its seeds prior to 1997 and the transformation of Albania's political and economic structures between 1997 and 2016, considering both achievements and failures. In this context, the paper seeks to use Albania as a case study 
example of a transformation process from a transitional democracy during the first post-communist years of 1990-1997, anarchy and disorder in 1997, when it was characterized as a regime type featuring a mix of democratic and autocratic traits (anocracy) in the Polity Score (Centre for Systemic Peace 2011), to the current situation which is characterized as a mixture of successes and failures, with labels such as it being a hybrid regime according to the Democracy Index (Economist 2016), a partly free country according to Freedom House's Freedom in the World Index (Freedom House 2016: 20), and a democracy according to the Polity Score (Marshall and Cole 2014). The belief is that the paper will point to lessons learned with respect to strategies directed at transformation processes.

The paper is organized into five broad sections. In the first section, the paper looks in more detail at what the existing literature provides for understanding what state disorder and conflict transformation means. It discusses in more detail conceptions of state disorder and conflict transformation and how they relate to the events of 1997 and their aftermath. The second section focuses on the empirical analysis and looks into the details of what happened in 1997. Section three spells out the conditions that prevailed prior to the collapse of political order. It documents the social and political configurations that were in place at the time of the economic and political developments that dismantled the state in Albania. The fourth section reviews Albania's transformation since 1997 from the perspective of politics, security, economics, and development. The fifth section draws conclusions.

To make sense of the 1997 disorder in Albania, in the next section I look at theories of state disorder and conflict transformation. In the remaining sections, I turn from deduction to empirics and explore the extent to which these conditions could be seen or were absent in Albania in 1997 and during the recovery period after 1997. The evidence leads me to conclude that in 1997, Albania had all the features of a disordered state and that in the aftermath of the events it has been able to transform itself successfully. 


\section{Theorizing state disorder}

The study of political disorders and cases of state failure has been central to the study of international security. A failed state is a country whose sovereign government does not function properly. The Fund for Peace characterizes a failed state or fragile state as having the following characteristics: "the loss of physical control of its territory or a monopoly on the legitimate use of force; the erosion of legitimate authority to make collective decisions; an inability to provide reasonable public services; and the inability to interact with other states as a full member of the international community" (Fund for Peace 2016: 13). In this paper, in order to comprehend what happened in Albania in 1997, I draw upon this definition and the characteristics it describes.

The literature focuses on the various reasons for the emergence of state disorder around the world. Some have focused on the relationship between ethnicity and the likelihood of political disorder (Easterly and Levine 1997; Fearon and Laitin 2003; Kaplan 1994). The political significance of resource wealth has also attracted much attention (Collier and Hoeffler 2004). Other scholars have also documented the close ties between resources and conflicts (Kakwenzire and Kamukama 2000). Bates sought to measure the impact of economic forces on state failure (Bates 2008). There are those who emphasize the impact of poverty (Sambanis and Hegre 2006). Others have argued that turmoil is more likely to occur during recessionary periods (Acemoglu and Robinson 2001; Haggard and Kaufman 1995). Another issue is democratization; it has been suggested that democratization can produce political instability (Mansfield and Snyder 1995; Snyder 2000) and that post-communist countries going through a process of democratization were vulnerable to disorder (Geddes 2003).

Applying the above framework of the reviewed literature to the case of Albania shows the limited applicability of some of the variables, including ethnicity and natural resources. Ethnicity played no role in the 1997 disorder seen in Albania. Although the country has several different clans, it is principally a mono-ethnic country. Natural resources also did not play any particular role, despite the fact that Albania has exceptional natural endowments for 
being a Balkan country. The management of natural resources has not been on the scale to affect the political order of the country.

Nevertheless, factors related to poverty and democratization played a more decisive role in the eruption of violence and civil unrest in 1997. Although the poverty rate has been decreasing year after year, poverty has been visible in the country throughout the transition period. In Albania, the poor were excluded from political power and, as such, they posed, as Acemoglu asserts, "a revolutionary threat, especially during periods of crisis" (Acemoglu and Robinson 2001: 939). Due to inequalities, Albanian democracy was likely to face ups and downs, something which contributed to the emergence of the 1997 disorder. Poverty encouraged the impoverished population to invest their last Leks in pyramid schemes that collapsed on the eve of 1997. Another factor to play a role has been the democratization process, more precisely the political cleavages and the political polarization of the society, between the right and left of Albania's political spectrum. In this context, this paper attempts to capture the impact of the economic and political structures and the developments in the country in the early 1990s (the independent variables) and assess their impact on the political disorder of 1997 (the dependent variable).

In 1997 Albania experienced the collapse of order and saw widespread violence, resulting in a situation where the government was overthrown and some 2,000 people were killed (Vickers and Pettifer 2007). The collapse of the government led to an anarchic uprising that brought Albania to the brink of civil war. During the events, large-scale confiscation and stealing of the state assets occurred. The events of 1997 ended one era and started a new phase in Albania's post-communist history.

\section{What happened in 1997?}

It all started in January 1997, with anti-government demonstrations all over Albania. People were protesting the collapse of pyramid schemes in which they had invested their savings. The unrest rapidly escalated 
into serious and armed riots in which protesters set fire to public buildings, ransacked town halls, courthouses, police stations and state banks, and destroyed thousands of official documents. There were armed battles in several towns between the police and the people. By the end of January 1997 the government had almost lost control of the country, as an armed revolt swept away the government's authority over most parts of the country (Biberaj 1999). The government's countermeasures included mass arrests, brutal beatings and the banning of protest demonstrations.

The dramatic and shocking riots culminated in March 1997, when the government declared a state of emergency and imposed a curfew. Arms depots were looted. Almost every family was armed. Tanks replaced normal traffic on the streets. The whole of the Albanian population had access to arms. The feeling that as far as the state went they were on their own, led the majority of citizens to shut themselves up at home in terror. The availability of arms led to emergence of potentially criminal thugs firing guns. Vast amounts of explosives stored in the depots were made available to people, often leading to turmoil around the depots. People were trading arms of which they had large quantities for wheat and supplies of which were running out. There were frequent incidents of robbery involving violence - car and bus holdups, machine gun robberies and attacks on police, which was virtually inactive. Unemployment was very high, as businesses had been destroyed during the rioting. Stores were robbed; schools and office buildings were badly damaged by vandalism. Violence escalated at the individual level as well. There was an unexpected revival of blood feuds, or revenge killings. An increasing number of people, as a result, were indirectly involved in blood feuds. The prisons opened, releasing criminals and political prisoners. Thousands of Albanians fled or attempted to flee on boats to Italy. Official censorship was imposed, outlawing foreign radio and television news programs. By mid-March 1997, almost the whole country, but particularly the southern part, was outside government control. Southern towns had set up their own governments, known as National Salvation Committees (De Waal 2005). March 1997 saw much of Albania in virtually a "total uprising". Vlora, a southern town, was at the heart of what was a major rebellion against the government (Nicholson 1999). Armed groups, or rebel national salvation committees, controlled most of the southern part of the country as they came into possession of weapons acquired through looting military 
barracks (Vickers 1999). These armed committees, led by generals that had visible connections with the traditions of the partisan struggle of World War II and composed of people that knew how to use light weapons (Vickers and Pettifer 2007), took control of the local governments as well as that of public order as the state ceased to exist in that moment. It resulted in an Albania with a number of different governments and different armies (Vickers and Pettifer 2007). In all the territories there were armed bands, that were stealing, killing, robbing, kidnapping, and blocking main roads, terrorizing the population by random shelling in the air, particularly in the evenings, at the time when the curfew time would start (Fuga 2008). The material damage, especially in parts of the south, was enormous. The overall picture was one of total breakdown (Vickers 1999).

The collapse of the pyramid schemes "dragged the country within weeks into anarchy, widespread violence, plundering, and food shortages" (Bezemer 2001: 2). When they collapsed, they swallowed a large share of the population's savings.

Social unrest spread rapidly as masses of demonstrating Albanians demanded compensation from the government and strong suspicions existed about its involvement in the schemes. These protests, six weeks of looting, the plundering of army arms depots and the emergence of irregular, armed bands caused the government to lose control over the larger part of Albanian territory. Significant parts of Albanian territory remain controlled by irregular, armed bands, the economy shrank to a level unprecedented in a decade, the incidence of random violence increased, and poverty rose dramatically. (Bezemer 2001: 6)

In 1997, the southern population, which had been affected most severely by the pyramid schemes' collapse, resorted to demonstrations and protests asking for the return of their money. Initially the revolt was economic, as the protesters were asking the government to release their money from the blocked accounts of the schemes. But, not long after, the economic revolt turned into a political and armed insurgency. The country was on the brink of civil war. Protesters wanted the resignation of the President Sali Berisha. The man who five-six years earlier in 1991-1992 was credited for the massive protests against communism, was this time asked to resign. He was held as being primarily responsible for the financial drama (Fuga 
2008; Vickers and Pettifer 2007). According to the incumbent Democratic Party (DP), the revolt was organized by the opposition Socialist Party (SP), supported by Greece, in order to destroy the state of Albania. SP spoke of the right of the population to overthrow a government, if necessary by force, which has not respected the rights of the people (Fuga 2008).

The events led to the collapse of the DP government in March 1997, leading to the formation of an all-party government, headed by a member of the rival SP. A multinational Italy-led armed mission was duly assembled to maintain peace and order in Albania and landed in the port of Durres in April 1997 (Vickers 1999). What followed were elections, which were held in June 1997. One of the primary reasons for holding the elections was to break the political impasse by giving the opposition, led by SP, a chance to form a new government that could ensure the return of sovereignty to the country. Although it was widely acknowledged that there was no chance of the election being entirely fair, it was seen nevertheless as the only hope of putting an end to the anarchy. The election day itself was marked by several acts of violence, which left at least four people dead and several injured. Notwithstanding these incidents, the elections were a democratic success, with the opposition socialists winning the election (Vickers 1999). In addition to voting against the incumbent government, in a referendum held simultaneously with the elections, Albanians also voted against the proposal of the government to restore the 1928 royalist constitution, which would see the monarchy of inter-war years return to the throne. As Albanian politics was still largely determined by the cycle of revenge, many of the incumbent government's most tarnished supporters were also supporting the idea of restoring the monarchy to save themselves from what they feared would be severe retribution following the formation of a Socialist government. There was a mass exodus of people implicated in some of the darker aspects of the incumbent DP administration. Key government office holders, including the interior minister, the chief of police, and the commander of the presidential guard that were blamed for the violence used during opposition rallies fled the country. A number of other office holders also left the country. The President of the Republic, unable to rule, resigned from his post (Vickers 1999), which brought to a close a half-year of chaos in the country. 
The catalyst for the 1997 disorder was the dramatic collapse of the pyramid banking schemes, in which Albanians had invested a massive amount of savings. "A large number of Albanians invested and lost their savings in funds that went bankrupt" (Sadiraj 1999: 84). Towards the end of 1996, news started to spread that these schemes would not be able to honour the promised profits on the investments. Panic started among the population. The interest-payments began not being made on time or they were significantly delayed. Rumours rapidly spread among the population that the money had already been transferred to foreign banks. The fever caught almost all parts of Albania. It was the largest national disillusionment of the transition period. People were not only calculating how much money they had invested, but also the potential profits that their investments into the pyramid schemes were supposed to yield. All the schemes collapsed suddenly, as the demands increased from the population that the money be returned. The loss was big and it was difficult to calculate in numbers. People had lost their money in one or more schemes (Nicholson 1999), but more than that, they had lost their dream of becoming rich. They were not able to forgive this loss. They needed to remove from themselves the responsibility and they wanted to identify who was guilty and punish them. Their desire was to be released from internal crunch through external aggression (Fuga 2008).

The schemes going bankrupt marked the start of the massive revolts against the government, which was seen by the protesters as a double culprit: for the fact that it allowed the pyramid schemes to operate and for the fact that it interrupted their work when it was expected that they would have yielded high interest rates. Many protesters claimed that the government established the pyramid schemes (Elbirt 1997). Nobody wanted to hear the government's arguments. They started to revolt violently against the state. The worsening of the 1997 crisis was part of the general crisis of Albania's elite following the break-up of communism, as they could not establish representative structures that would mediate between the regular Albanian population and the national authorities (Vickers and Pettifer 2007). During the first weeks of 1997, almost all the schemes declared bankruptcy (Fuga 2008). Large numbers of Albanians 
(as well as some foreigners) had put money into the schemes and many lost everything, including in some cases their apartments, which had been sold to increase investment capital. The main factor that explains the widespread participation in the schemes was the limited availability of alternative income generating possibilities within Albania, which itself is linked to the absence of a financial infrastructure. The duration of the pyramid schemes over a long period, having sprung up in the early 1990s, encouraged people to believe that the schemes actually represented productive investments. There was the well-founded belief by many that the schemes were based on illegal activities of a highly profitable nature, such as arms, drugs and people smuggling, including illegal oil sales to neighbouring Kosovo and Montenegro. The sanctions imposed by the UN on neighbouring Yugoslavia because of the war offered opportunities for pyramid schemes to benefit from the proceeds of oil smuggling. Significant volumes of oil were imported to Albania and then shipped over land to Kosovo and Montenegro. However, the lifting of sanctions on Yugoslavia in 1995 led to the loss of the lucrative illegal oil market, which in turn had a negative impact on the sustainability of the pyramid schemes. The loss of the steady income from smuggling set in motion a downward spiral that ended in the dramatic crash of the pyramid schemes (Abrahams 2015).

Furthermore, in March 1996, the government exempted the pyramids from a banking law which would have regulated them. In July and August 1996, when growing competition between the schemes would naturally have led to their collapse, the government intervened to sustain them. In this way, the pyramid schemes attracted millions of Leks from a population that was indebted and unemployed, convinced that drugs, arms, oil and people smuggling guaranteed returns on their money (De Waal 2005). Investing in the 'pyramid' banking schemes that had sprung up in every major town was seen as a way for the population to supplement their limited incomes (Vickers 1999). By early 1997, the total value of pyramid deposits was estimated to amount to US $\$ 1.2$ billion or some $50 \%$ of GDP (Bezemer 2001). Others estimated that they amounted to some US $\$ 2$ billion (Vickers and Pettifer 2007). The schemes were using the money invested by others to pay out the interest owed. Pyramid schemes, also known as ponzi schemes, are a form of fraud in which quick returns to the first investors come from money invested by later investors. Pyramid banking schemes, as Sadiraj puts it, "are games where individuals or 
companies pay out funds to some parties by borrowing funds from others. To survive, they need to use invested funds to pay other investors. When there is insufficient money left as investors start to withdraw, they collapse" (Sadiraj 1999: 85).

Almost every Albanian family had invested money into one pyramid scheme or another. Nearly every family lost hard-earned savings (Vickers 1998). Thousands of people would queue from the early hours of the morning to deposit their savings, much of it earned doing hard manual labour abroad. The seriousness of the looming pyramid banking crisis had not been anticipated by either the government or international financial institutions, although some warnings had been issued by the World Bank and the International Monetary Fund as early as October 1996. The government did not take any action and the schemes continued to operate as before (Vickers and Pettifer 2007). By early January 1997, however, the country was suddenly catapulted by the dramatic collapse of the pyramid schemes. Depositors flocked to withdraw funds, thereby setting off the process that led to the collapse of the state in March 1997 (Vickers 1999).

Albanians trusted these financial schemes and did not understand that they could collapse. The schemes received wide publicity. Newspapers published indexes of interest rates given by schemes on a daily basis. Their appearance in the media made the schemes appear trustworthy in the eyes of the population. The then President of the Republic declared that the money of Albanians were the cleanest in the world (Fuga 2008). Indirectly, this meant legitimizing the work of the foundations whose bank accounts were sitting in the state owned banks. Even the opposition socialists did not criticize the schemes, making the public believe that there was nothing wrong with the schemes. The socialists were not able to criticize the schemes, as undermining the schemes would have affected its electorate, which was mainly concentrated in the South, which was also heavily involved in schemes (Fuga 2008).

Albanian society at that time had an economic profile of possessing cash, which was not deposited and could be circulated in the informal economy. One substantial part of the money was coming from work abroad, either from personal work or from family members working in 
those areas. It was also difficult to keep illegal money gained in Albania in the banks due to the political instability, but also the fear of having to disclose the source of money. Thus, there was a surplus of cash that was circulating that was unaccounted for and which was thus invested in pyramid schemes (Fuga 2008).

The schemes became massively accepted by the population also as a form of replacement for the absence of a social insurance system. The old social system during communist times, which offered free medical treatment, low rents, vacation vouchers, and pensions, had collapsed. Although limited at that time, the pyramidal system offered people indispensable security. This was particularly helpful for the elderly, unemployed, and poor. The collapse of the pyramid schemes led to the social collapse of society; the old bonds of society were not functioning anymore, leading to social anxiety. This anxiety made society accept any offer that would help them to get out the crisis that they were facing. In this light, the pyramid schemes offered Albanians a new source for social security and offered a basis for the desire to live in luxury (Fuga 2008).

The collapse of the pyramid schemes was the catalyst of the 1997 disorder. However, there were also deep structural reasons that caused the collapse, including corruption, criminality, lawlessness, political polarization, insecurity, and lack of economic growth. The seeds of the 1997 revolt were sown earlier, in the period of 1990-1996. The fall of the pyramid schemes was the catalyst for a revolt that would have eventually occurred in any case. It was the beginning of a second attempt by the Albanian people to establish democracy (De Waal 2005).

The corruption of the government had been fuelling public anger and resentment for a long time (Kajsiu 2010). During the same period, the degree of corruption at ministerial and local government levels was becoming the source of widespread concern and growing cynicism on the part of the population (Muco 1997). Resentment was further fuelled by the state's cavalier attitude to property disputes and inadequate legislation (De Waal 2005). For several years in Albania there were ideal conditions for engaging in criminal activity. There was a growing lucrative illegal cross-border trade in arms, fuel, drugs, and people, carried out with the blessing of the government (Vickers 1999). The general impression 
was that crime was establishing throughout Albania and that society was sinking into rule by criminals and their associates (Vickers 1999). Albania became the epicentre of a new Golden Triangle that was "formed in south-eastern Europe for the transit and production of drugs" (International Crisis Group 1999: 4). In several southern cities there were cocaine refining laboratories. Drug syndicates used Albanian ports to transport narcotics to Western Europe. Marijuana and cannabis were cultivated at numerous sites throughout the country.

A growing number of Albanians were becoming involved in the narcotics trade as farmers, traders, couriers and motorboat owners. There were sizeable profits to be made in a region otherwise devoid of industry, and due to the lack of any other source of income, the prosperity that the drugs trade brings was regarded locally a stabilising factor. This way, Albania's image as a rouge state, harbouring criminal mafia was enhanced. (International Crisis Group 1999: 7)

The divisive forces along tribal, provincial and political lines that for a long time plagued Albania re-emerged during the period of 1990-1996. Rifts between rural and urban folks, the north and south, Ghegs and Tosks, democrats and communists, were the re-emerging characteristics of Albanian transitional society. Dogmatism and revenge were dominant features of government-opposition relations, contributing to an overall climate of intolerance. Indeed, a number of democratisation initiatives were blocked by this wild rivalry (Vickers and Pettifer 2007). The government turned its attention to the settling of old scores (Vickers 1999). The initial signs of what was to come in 1997 could be seen during the May 1996 elections when the opposition SP disputed the electoral results. Demonstrations were held in various parts of the country, which often resulted in confrontations between protesters and the police, which was often brutal in its treatment of the demonstrators. This started to lead to a loss of legitimacy of state institutions in the eyes of the wider public and that of the international community. The international community denounced the acts of the police. Opposition newspapers regularly published photos of injuries people had obtained during demonstrations. The ideology of the incumbents at the time was that there existed a risk of return of communism to Albania in the face of SP. This feeling did not allow the DP to accept the transition of the government to socialists and 
it was clear that it would not allow it to happen without the use of brutal force (Fuga 2008). The government lacked tolerance of dissent, and the courts and secret police were used to intimidate and imprison political opponents. In 1995, a law misleadingly named the Genocide Law was passed. The law banned all senior Albanian communist officials, members of pre-1991 governments and collaborators with the intelligence services, from public positions for six years. The Genocide law was both arbitrary and draconically enforced by the DP government (Austin and Ellison 2008). Anyone who had been a prominent communist was banned from all public sector jobs for the next few years. Socialists could no longer apply for loans to set up or expand a business (De Waal 2005).

Initially, Albanians had expected quick returns from their investment in democracy. However, their growing political maturity was producing a crisis of confidence and disillusionment with the democratic process, which in turn led to rising social discontent. Frustration grew as the promised job prospects and progress in terms of living standards failed to materialize (Vickers 1999). People were not better off than before the establishment of democracy (De Waal 2005).

The absence of an organized policy for Albanians migrating across borders was one of the earliest and most persistent sources of resentment towards the government. From the government's point of view, laissez-faire meant that Albanians continued to move abroad illegally in large numbers, sustaining the domestic economy and keeping serious discontent among the unemployed at bay (De Waal 2005).

Although many economies have had pyramid banking schemes, nowhere else were they observed to dissolve society as they did in Albania. Among the features of the Albanian experience were caused by the already polarized political scene and the ready availability of arms in the many army depots throughout the country. The problems were eagerly exploited by the socialist opposition to win the population's support. It supported rebel claims for a "political solution" to the problems. These circumstances allowed a sudden and widespread economic problem to turn quickly into a political and also a physical, territorial battle. (Bezemer 2001: 13) 
The pyramid schemes did not only exist in Albania. Similar schemes were present also in neighbouring Macedonia, Bulgaria, Romania, Russia and elsewhere in post-communist Europe in the 1990s (Vickers and Pettifer 2007). In Macedonia, a savings bank named TAT collapsed in 1997, erasing the economy of an entire major city, Bitola. The government, facing elections, acted quickly and offered compensation to the afflicted savers (Vaknin 2009). However, very few countries experienced the speed of Albania in the spread of the pyramid schemes and surely no other country had experienced destruction that was so shocking to the social order that the country came close to the brink of civil war following the closure of the pyramid schemes (Vickers and Pettifer 2007). The impact of the collapse of the pyramid schemes was especially destructive in Albania due to their widespread popularity among the population, their unprecedented scale relative to the size of the economy, the clientelistic nature of the political, economic and social context of the country, and the fragility of political culture - factors that would all have important consequences for what was to come after the collapse of the pyramid schemes in Albania. The nominal value of the pyramid schemes' liabilities amounted to almost half of Albania's liabilities and about two-thirds of the population invested in them (Ayers 2015; Elbirt 1997; Jarvis 2000; Krasniqi 2014). It has been repeatedly argued that the politico-economic system in Albania is characterized by the existence of clans and that the communists, the first democratically chosen government and socialists later applied policies that favoured specific clans (Gerxhani and Schram 2000b). The clans have significant influence in Albania.

There is an important cultural and linguistic polarization in Albania. This polarization is geographically based, dividing the country into a northern and a southern region. Historically, the polarization of society runs parallel to the existence of two main clans in Albania, the Ghegs (northern-based) and the Tosks (southern-based). They go back far in history. (Gerxhani and Schram 2000b: 21)

Indeed, the first democratically elected government, led by DP, appeared to favour the clan whose major support is in the north, and the then opposition SP, just like Enver Hoxha, had favoured the other, southern clan. After 1992, this was the situation, as described by Gerxhani and Schram: 
[E]very ministry and institution was loaded with northerners and DP loyalists, and [...] their appointment to ministerial office and other positions was accompanied by a vast migration from the north to Tirana as families sought to capitalize on family members and friends who were now holding high office in the capital. It also appears that [the] DP government redistributed funds in favour of the northern clan. Hence, the relative position of the north improved. This led to a polarization of the Albanian society in two main and antagonistic groups: pro- and anti- communists, southerner and northerner. One of the characteristics of a clan culture was the distinct voting behaviour of various groups. Support for the DP was therefore significantly lower in the south than in the north. Voters also reacted differently to policies by the party concerned, dependent on the clan they related to. In Albania, this would imply that voters in the south would react differently to DP policies than voters in the north. In the south, partisans reacted very strongly to economic swings attributed to the DP government because they were more sensitive to these policies than a non-partisan would be. Partisans in the north have had a strong alliance with the DP irrespective of its policies. The relationships between parties and regional groups have many of the characteristics that can lead to classify the DPA and SPA as clientelistic parties. (Gerxhani and Schram 2000a: 309)

During the 1992-1997 period, already existing regional (north vs. south), cultural (Ghegs vs. Tosks) and political (right vs. left) polarization deepened. This north/south polarization and conflict has been an integral element of Albanian politics (Austin 1993). This polarization came also to play a role in peoples' responses to the events of 1997. The north was not as vocal as the south was as regards to the 1997 events. Militarization was heavier in the south than in the north. Armed groups were more widespread in the south than in the north. The events of 1997 came to have an element of the south revolting against the DP government, which was mainly staffed by northerners. The democratic and socialist camps were divided in their political orientation and their respective "truths" were largely mutually exclusive (Schmidt 2002). Enmity between these two rival factions would repeat itself in different cycles, including in 1997 (Stefani 2005). 
Another feature of 1992-1996 period was the increasingly authoritarian rule in Albania. Scholars often treated Albania like regimes at the time with names such as incomplete or transitional forms of democracy, anocracy, hybrid regime, competitive authoritarianism or semi-democracy. In their work, Levitsky and Way (2002) defined the regime in Albania of the early 1990 s as

\begin{abstract}
"competitive authoritarian, where formal democratic institutions are widely viewed as the principal means of obtaining and exercising political authority and where incumbents violate those rules so often and to such an extent, however, that the regime fails to meet conventional minimum standards for democracy" (Levitsky and Way 2002: 52).
\end{abstract}

The expectation was that Albania would remain a hybrid regime and move further in an authoritarian direction (Levitsky and Way 2002). It was suggested that we stop thinking of Albania and similar cases in terms of them going through a "transition to democracy" and to think of them as "specific types of regimes as they actually were" (Levitsky and Way 2002: 51).

How did Albania become a competitive authoritarian regime? Following the collapse of the communist regime in 1990, Albania, as a result of domestic and international pressure, did what almost all the former communist countries in Central and Eastern Europe did and adopted formal democratic institutions. The adoption of democracy in Albania had a responsive character. On the one hand, the initial democratization efforts developed spontaneously as a response to the pressures and penetrative impact of European integration on post-communist Eastern Europe. Albania established something resembling a democratic system and a market economy, but this was a matter of adopting what was the norm for post-communist countries. On the other hand, there was also a strong intention to transfer into Albania's political system the values, rules and regulations associated with European democracies. While it had outside help, the initiative came also from within. Albania experienced a harsh version of communism, and there was pressure for change that developed in the country itself. However, there was little understanding and/or enthusiasm for adopting and applying the requirements of democracy, as can be seen in the Albanian government's reluctance to establish a proper democracy. Thus, during 
the brief period of liberal democracy that followed the regime change in 1990, relatively authoritarian attitudes came to shape the behaviour of the new authorities' behaviour, including with regards to the "semifree press, regular scrutiny from opposition members of parliament, and a quasi-independent judiciary" (Levitsky and Way 2002: 61). Due to the lack of checks and balances on the exercise of power, the new postcommunist authorities manipulated or selectively adhered to democratic rules. With the collapse of centrally maintained order under communism, the new authorities were not adept at imposing a similar level of peace and order in society. The lack of democratic traditions and the weak civil society culture created opportunities for the DP elected government to rule autocratically. The DP governments engaged in a series of abuses, including exercising tight control over media, and the harassment and arrest of opposition leaders (Angjeli 1995).

In 1990, when Albania started its post-communist phase, it was a very poor, weak state, with no civil society and no private sector, and there were political cleavages between the beneficiaries of communism and those that were oppressed. The emergence of a multi-party system, starting from December 1990 - a month which is celebrated to mark the beginning of democracy in the country - would bring pluralism and freedom of expression to the country. However, it would not bring immediate economic results as was hoped by the majority of the population that had wanted change in the country. The opening of country to democracy in 1990 was celebrated by the population through continuous and violent demonstrations throughout this initial period of the post-communist transformation (Gjoka 2003). This period would be the first phase of the chaotic transformation of Albania. In this period, almost all communist era production facilities, mainly in agriculture, would either go bankrupt or were closed down by the authorities. Public infrastructure and facilities were either robbed or destroyed by angry riots. Tens of thousands of people illegally emigrated to either Italy or Greece (Vickers and Pettifer 2007). All that was happening was an expression of the revenge of the people for what they suffered during communist times (Gjoka 2003).

All the reasons were in place for competitive authoritarianism during the period of 1992-1997. DP was confronted with important domestic impediments to the consolidation of its regime. To fully consolidate 
its regime, it eliminated all major sources of contestation through the imprisonment of its opponents. Resource scarcity made it more difficult for the DP to sustain its patronage, or clan network and it therefore tolerated the emergence of new economic practices such as pyramid schemes and cross-border drug trading that aimed to sustain the new regime's structures and facilitated the establishment of neo-patrimonial structures. As it was able to overcome domestic obstacles, it was also able to overcome the international obstacles to its rule in the early 1990s, more precisely between the years of 1992-1996. In this regard, it benefited from a "permissiveness in the international system, due in large part to economic or security issues that trumped democracy promotion on Western foreign policy agendas" (Levitsky and Way 2002: 62). However, the growing dissatisfaction that led to the civil unrest in 1997 also led to end the international permissiveness and made it difficult for the DP government to be able to sustain the regime. Thus, the events in 1997 brought this regime to an end. Also, all that was achieved was demolished in 1997 (Bezemer 2001; Sadiraj 1999).

The regime change in 1990 brought major changes to Albanian society; it was a historical change in this nation's history. However, it also brought a power vacuum that the new post-communist authorities did not have the capacity to fill. All incentives for structural change were exhausted. Instead, the DP government tolerated informal economic structures such as pyramid schemes and cross border drug trading. These schemes interrrupted Albania's transition from democracy enthusiast to a state with strong democratic credentials. The increasing political polarization and the collapse of the pyramid schemes revealed the weakness of the Albanian state. People suddenly found themselves able to articulate their grievances and justify their actions. As such, it opened the way for a popular uprising. People were also not satisfied with the way the land reform and privatization had been conducted, as the policies were divisive and led to dissatisfaction among all sides (Vickers and Pettifer 2007). The collapse of the pyramid schemes had a snowball effect on the domestic changes and caused the reform agenda in the country to deteriorate. It brought destructive dynamics to Albania's politics and economy, which led to the 1997 disaster.

Ismail Kadare, the most prominent Albanian writer, also had a say in the 
1997 events. He reacted in his own unique style with a novel dedicated specifically to the 1997 disorder. Disappointed with the 1997 unrest, Kadare warned metaphorically that the newly planted democratic flowers in Albania were threatened by frost and that Europe should take due measures to protect them. For him, 1997 was a reflection of Albania's struggle to gain freedom and liberty (Kadare 2005) and to maintain order amid the anarchy of freedom, where old traditions and new values were in competition (Kadare 2000).

\section{Transformation of Albania's political and economic structures since 1997}

The crisis of 1997 was too costly in many respects and "affected all the political, military, social and economic aspects of life in the country" (International Crisis Group 1999: 11). However, Albania was able to recuperate politically and economically. With macro-economic stability emerging in 1998, Albania's economy grew significantly and transitioned to a rapid economic recovery. Political stability as a whole increased as the political polarization and cleavages that haunted the political economy in the 1990s started to recede (Yusufi et al. 2012). As the 1997 crisis and state collapse affected everybody, it came to have implications in overcoming the divides in society. It may be the case that the 1997 events set in motion a change in patterns of north-south polarization, as everybody was affected by the events. This paper argues that the 1997 events, because they sped up the process of democratization, also came to play a role in overcoming the north-south divide. It has led to a political environment where clientelism has become less of a feature of the appeals of parties to voters. In the aftermath of 1997 , there has been an improvement in the functioning of government institutions, which has been key to overcoming clientelism. This has given post-1997 Albania an opportunity to break the traditions and structures of clientelism. The events of 1997 reflected the division of north and south; however, the country has more and more come to have a national character rather than being torn by clan based divisions. Although the rebellion was initially concentrated in the south, it spread to the central and northern territories of the country, making it a national event. Therefore, the 1997 events, although 
initially capitalizing on the existing divisions between north and south, was not a south-only rebellion - it became an unrest affecting all of Albania.

The pyramid scheme crisis, and the resulting political and armed chaos, regardless of all the negative sources and results, brought, in a paradoxical manner, the finalization of the political transition in Albania. The parties accepted the change in the government. This is important to take into account in judging the democratic level of the state. This was the first rotation of the government and it was successfully closed. Thus, the elections held in June 1997 brought about a change in the government through voting. It was the first change of government after the end of communism (Fuga 2008).

After restoring order towards the end of 1997, the situation was sharply reversed again following the killing of Azem Hajdari, one of the founders of DP and a leader of the 1990/91 student demonstrations that brought about the fall of the communist government. The country was threatened once more by the prospect of civil chaos.

The Albanian people generally, however, had no stomach for a repeat of the previous year's horrific violence. Although they were undeniably dissatisfied with the performance of new administration, the overriding attention of the population was focused on finding the means for survival amidst the country's economic ruin. (Vickers 1999: 253)

Also, the start of dialogue between the government and opposition was seen as positive and as a step "towards healing the deep political wounds that [have] scarred Albanian politics" (International Crisis Group 1999: 1).

In the aftermath of the events of 1997, Albania made progress in reestablishing peace and order in the country. Military committees were dissolved. However, only a fraction of stolen arms were collected.

A serious factor contributing to worsening social relations was the large number of weapons still in civilian hands since army depots were looted in the spring of 1997. It was estimated that 656,000 weapons of various types were looted from army depots 
in March 1997, together with 1.5 million rounds of ammunition and vast quantities of hand grenades and land mines. Despite much discussion, however, attempts to disarm the population proved fruitless. By the end of 1998, only 97,000 weapons (excluding mines and ammunition) had been retrieved. (Vickers 1999: 253)

The rest remained in the hands of the population, contributing to the climate of criminality still present in the country. The armed population and the return of public security therefore represented the "gravest and most complicated challenges for the Albanian government" (International Crisis Group 1999: 6).

Kosovo, now a separate independent state of Albanians, but in the 1990s still part of Serbia, was one of the hurdles to a successful transition in Albania after 1997. The Kosovo question, which led in March 1999 to NATO's intervention against Serbia, became an integral part of Albanian domestic politics in the post-1997 era. As Albania was moving towards recovering from the 1997 crisis, it faced the challenge of how to deal with the hostilities in neighbouring Kosovo in 1998-1999. But Albania, despite expectations to the contrary, encouraged a peaceful solution to the problem (Austin 1993). A key moment was during and in the aftermath of the 1997 disorder, when Albania is believed to have supported the Kosovar Albanians to launch their armed campaign against Milosevic's Serbia - in terms of weapons and a base from which to launch attacks (Vickers 2008). The flare up of the war in Kosovo in March 1999 led to a massive exodus of Kosovar Albanian refugees to Albania, which immediately responded with immediate assistance to meet the needs of the refugees (Johnson 2010). The Kosovo crisis further intensified the contacts between Albania and the EU, and the EU started to invest heavily in the provision of aid aimed at re-establishing control over the security sector (Levitsky and Way 2010).

After 1997 the country reformed its security sector, including the police, army, intelligence and other security institutions, seeking to ensure the security sector was able to meet its contemporary obligations and challenges. This success was crowned with full NATO membership in 2008. In the process of approaching the EU and NATO, Albania took on many new security obligations and responsibilities and actively participated in international peacekeeping and peace supporting operations, such as those in Afghanistan, Chad and Bosnia and Herzegovina. Adopting NATO 
standards and providing support to peace missions brought security actors such as the army and the police in the country closer to meeting international standards. Immediately after the events of 1997, Albania embarked on security sector reforms, which included the establishment of new institutions, structures, and chains of responsibility for the security sector (Yusufi 2003).

Economic growth following the regime change in 1990 fell by 29.6 per cent in 1991, and the economy contracted by 10.2 per cent in 1997 due to the civil unrest. During the period 1991-1997,

"Albania experienced a post-communist transition that led the country to become one of the poorest, if not the poorest and the least developed economy in Europe. The underlying strengths of the Albanian economy led to recovery in 1998 with robust GDP growth of 12.7 percent that year. The economy grew by over 80 percent over the thirteen-year period of 1998-2010, one of the highest sustained rates of growth in Europe. Once labelled as the continent's poorest country, Albania has been one of the fastestgrowing economies in Europe. Today, Albania is a lower middleincome country, and graduated from the World Bank's IDA lending for only-poor countries in 2008. The country has also experienced rapid social change, including internal migration from rural to urban areas and mass emigration of economically active citizens who are a source of substantial remittances (ranging from 11-14 percent of GDP annually)." (Yusufi et al. 2012: 5)

While Albania has a considerably smaller economy than other European states, it is an open economy that is highly integrated into international trade markets. It undertook significant reforms to many aspects of its economy over the past few years, including improving the business environment and the transport and energy infrastructure. The business climate also improved and a number of leading foreign investors expanded their operations in Albania. Steps taken for purposes of administrative streamlining also improved the investment climate. As a result, Albania succeeded in attracting US\$4 billion in net FDI during the period of 2007-10. Significant levels of corruption, however, and weak property rights have been a substantial drag on economic activity (Muco 1997). 
Albania's economy has grown significantly and slowly transitioned to a state of economic recovery; the overall political stability has also improved in recent years. "EU accession is highly popular and remains the anchor of reform in nearly every area of the government" (Yusufi et al. 2012: 10). All of these provide good grounds for having the country pay attention to tackling its specific development achievements. Albania's development achievements are substantial. With a GDP per capita of $\$ 3,960$, and a Human Development Index score of 0.751 (with a rank of $70)$, the country has reached a high level of human development. Along with 188 other countries, Albania has pledged to achieve the MDGs and the nation seems well-placed to meet most, if not all millennium targets by 2015. Albania's strong economic growth has been a major contributing factor in its positive steps towards achieving the MDG targets. It is on track to achieve its MDGs, including with respect to poverty reduction, child and maternal mortality and in regards to combating diseases (Yusufi et al. 2012).

Rapid GDP growth in Albania has been accompanied by an equally impressive decline in poverty. Nearly half of Albania's poor were lifted out of poverty between 2002 and 2008 and the poverty head-count fell from 25.4 per cent in 2002 to 12.4 per cent by 2008 . Extreme poverty is very low. More than 50 per cent of the population lives in rural areas, home to half of its poor people. Poverty reduction was initially more pronounced in rural areas (29.6 per cent in 2002), but the decline in rural poverty has accelerated substantially over the past years and is now approaching urban rates (14.6 per cent in 2008). Nonetheless, there are areas of the country - mostly mountain areas - where poverty remains high (29.8 per cent). Poverty is particularly evident in depressed regions that lack industries. In addition, in the rural areas, female-headed households have experienced only one-third the rate of poverty reduction as maleheaded households have due to the difficulties for women to access job opportunities and the lack of women-specific measures of empowerment in the labour market. Albania's strong economic performance has been accompanied by positive changes to employment. Between 2002 and 2008 , the unemployment rate decreased from approximately 17 per cent to 12.8 per cent (Yusufi et al. 2012). 
Although there have been notable improvements to Albania's social indicators - for instance, enrolment has increased at all levels of education - the nation remains an outlier with respect to the goal of achieving universal primary education. Albania also faces significant challenges in promoting gender equality, empowering women, and in ensuring environmental sustainability. With respect to infrastructure development, a high proportion of the population (82.1 per cent) had access to potable drinking water as of 2009 , though the 2015 target of 98 per cent will likely not be reached. With a strong probability of continued domestic and external financing that focuses on sanitation, it is likely that the 2015 target of 90 per cent of the population having access to sanitation can be reached. Challenges do remain in a number of other MDG target areas. While there has been a decline in unemployment since 2002 - to the level of 17.7 per cent (2015) - it did not reach the targeted 9 per cent level by 2015 (Trading Economics 2017). Challenges related to rural-urban, regional and gender related inequalities also remain.

The status and position of women in Albania has been a development challenge; however, the country has made substantial progress in setting standards and passing laws to promote equality between men and women. Albania has also worked hard to improve the lives of women and girls throughout the nation and overall; the country can be considered to be moderately advanced in implementing gender equality rules in its governance systems. Albanian gender equality legislation also carries mandatory percentages or quotas (30 per cent) for women in political office and ensures this representation through an authority that monitors progress. The introduction of a 30 per cent quota of representation has ensured a strengthened balance of participation for men and women in decision-making; however, in practice the quota level has yet to be achieved. Albania has made progress in tackling gender-based violence, although a 2009 survey concluded that more than 50 per cent of women have experienced some form of physical, sexual, psychological or emotional violence and abuse (Haar and Dhamo 2009). An increase in reported cases of domestic violence following the introduction of this new law attests to the fact that family violence continues to affect many families in Albania, while cases are under-reported, particularly in rural areas. Women are under-represented in the labour market in Albania, with their economic activity being lower than men. Women experience unequal 
access and control over resources (e.g. property, land, credit, etc.) and a much higher proportion of women work in lower skilled occupations. This is due, in particular, to the insufficient allocation of human, technical and financial resources for the effective implementation of laws and strategies that relate to women's access to and treatment in the labour market. Women's employment, although still lower than men's, has seen a slight increase, with an increased presence of women in the agriculture sector. Albania remains a country of origin of women trafficked for the purposes of sexual exploitation and forced labour; however, there has been a decline in the number of persons being trafficked. Notwithstanding improvements in the situation of women, Albania has kept the same place in the Gender Gap Index of the World Economic Forum (rank78) because of a belowaverage performance in terms of female educational attainment.

Post-1997 Albania experienced a combination of political and economic stability. It has had coalition governments with broad public support, and favourable long-term population dynamics. These circumstances provided Albania with a historic opportunity, by continuing its strong economic policies, to achieve sustained high income growth and better lives for the Albanian people (Yusufi et al. 2012). Post-1997 governments were not able to continue along the same path, as the 1997 events reminded the new government of the power of popular resistance, but also because the state of Albania in the aftermath of the 1997 events was not tolerated by the international community and did not have the capacity to coopt or repress opposition challenges. In post-1997 Albania, control over state and economic resources became fragmented, which generated political competition. What was also important was the emergence of a civil society able to voice and provide checks on the behaviour of the government.

Substantial changes occurred in the country only as the result of shocks of the 1990 regime change and the 1997 unrest. The 1997 disorder represented a second shock in Albania's post-communist history after that of the 1990 regime change. The 1997 crisis was instrumental in shaping the political and economic transformation of post-1997 Albania. The 1997 disorder became an important reference for measuring the progress of reforms in the country. The post-1997 reforms thus became locked in a pattern, where the transformation of the political and economic 
structures that led to the 1997 events became a priority that no post-1997 government could escape. The strong commitments that were made by the international community after the 1997 crisis with regards to Albania's transformation became a particularly strong mechanism influencing the path dependent pattern. The logic of action of the political establishment early on became closely connected to protecting the peace and order that was established after 1997 as a symbol of the successful conflict transformation. The attachment to maintaining peace and order was not particularly surprising, as changes in the country from the inception of the pro-democratic reforms in 1990 have been developed in response to external pressures and shocks.

Reviewing the developments in post-1997 Albania, the new governments in the post-1997 period have provided the basis for major changes in the country. Despite weaknesses in relation to the democratization process, what Albania went through was a profound transformation that led in the medium term to a regime change, from being a competitive authoritarian regime to being considered a candidate for proper democracy. The post1997 period has led to a major political reorientation for Albanians, with increased cultural, economic, as well as political contacts (Vickers and Pettifer 2007). In post-1997 Albania, modernization and westernization (or Europeanization) has been highly popular and remained the anchor of reform in nearly every area of Albania's governance. The country has struggled to overcome disparities in income levels across the country, improve the regulatory environment and tackle corruption. It has also faced challenges in implementing reforms aiming to give it a market oriented economy, build democratic institutions and strengthen the legal system (Yusufi et al. 2012).

\section{Conclusions}

This paper has attempted to explain the phenomenon of state disorder and its sources, including an analysis of war-like economic structures in weak states and how they are a major source of state disorder. The events in Albania in 1997 illustrate what can happen when war-like economic 
structures are tolerated in situations of weak political and economic governance. In 1997, law and order in Albania collapsed, with civil unrest spreading to all parts of the country. The 1997 unrest, the catalyst of which was the collapse of pyramid schemes, hit the country hard and created a security vacuum that sparked anarchy and political and economic collapse, with all the elements that made it become a case of state failure in Europe. The state disorder seen in 1997, in turn, despite expectations to the contrary, led to a profound transformation of the country. The 1997 disorder, after all, did not have an overall negative impact on the country's future. It came to represent a benchmark for the country in its path to political and economic modernization. Despite some temporary economic and political crises, the country has gone through a substantial political and economic transformation, during which some of the old political and economic characteristics that are distinct to the country, such as political clientelism, cleavage and polarization, entered its phase of retreat. A number of economic structures closely resembling the structures seen in war-type economies receded with the coming to a halt of the 1997 events. Nevertheless, a number of other political and economic structures remain and survived and stand to play a path dependent role in the country's political and economic transformation. Still, the disorder of 1997 had an influence that helped the country overcome the legacies of the past and helped transform the society for the better. It led to a quick recovery and had a transformational effect on Albania's politics, security, economics and development. This study has attempted to capture the impact of war-like economic and political structures on state disorder, and represents an important step towards understanding cases of state failure in the developing world.

Albania's experience has significant implications for other countries in which conditions are similar to those that led to the disorder in Albania. Albania's experience contains some important lessons. There are steps governments can take to limit the possibilities for the existence and spread of pyramid schemes and to tackle political and economic governance problems. Albania's 1997 experience is a powerful reminder of the costs of an unchecked transition. 


\section{B Bibliography}

Abrahams, F., 2015. Shaiperia e re. Nga diktatura ne demokraci ne Europe. Tirana: Fjala Publishing.

Acemoglu, D., and Robinson, J. A., 2001. A theory of political transitions. The American Economic Review, 4: 938-963.

Angjeli, A., 1995. Problems of Albanian Democracy. Mediterranean Quarterly, 4: 35-47.

Austin, R., 1993. What Albania adds to the Balkan stew. Orbis, 2: 259-279.

Austin, R. C., and Ellison, J., 2008. Post-communist transitional justice in Albania. East European Politics \& Societies, 2: 373-401.

Ayers, B., 2015. Bridging the gap. Defining progress in the fluid context of Albania's first ten years of democracy. Morisville: Lulu.

Backer, B., 1982. Self-Reliance under socialism - the case of Albania. Journal of Peace Research, 4: 355-367.

Bates, R. H., 2008. When things fell apart: state failure in late-century Africa. Cambridge: Cambridge University Press.

Bezemer, D. J., 2001. Post-socialist financial fragility: the case of Albania. Cambridge Journal of Economics, 25(1): 1-23.

Biberaj, E., 1999. Albania in transition: the rocky road to democracy. Boulder, CO: Westview Press.

Centre for Systemic Peace, 201 1. Polity IV Country Report Albania. Vienna, $\mathrm{VA}$.

Collier, P., and Hoeffler, A., 2004. Greed and grievance in civil war. Oxford Economic Papers, 56: 563-95.

De Waal, C., 2005. Albania today: a portrait of post-communist turbulence. London: I. B. Tauris.

Easterly, W., and Levine, R., 1997. Africa's growth tragedy: policies and ethnic divisions. Quarterly Journal of Economics, 112: 1203-50. 
Economist, 2016. Democracy Index, 21 January 2016.

Elbirt, C., 1997. Albania under the shadow of the pyramids. Transition, 5: $8-10$.

Fearon, J., and Laitin, D., 2003. Ethnicity, insurgency and civil war. American Political Science Review, 1:75-90.

Freedom House, 2016. Freedom in the World Index, January 2016.

Fund for Peace, 2016. Fragile States Index, 27 June 2016.

Fuga, A., 2008. Media, politika, shoqeria: 1990-2000. Tirana: Botimet Dudaj.

Geddes, B., 2003. Paradigms and sand castles. Ann Arbor: University of Michigan Press.

Gerxhani, K., and Schram, A., 2000a. Albanian political-economics: Consequences of a clan culture (No. 92). LICOS Discussion Paper.

Gerxhani, K., and Schram, A., 2000b. Clientelism and polarized voting: empirical evidence. Public Choice, 141: 305-317.

Gjoka, N., 2003. Sfida të një tranzicioni të vështirë: Kronika, Analiza, Refleksione, Ese e Meditime: 1991-2000. Tiranë: Globus R.

Haar, R. N., and Dhamo, M., 2009. Domestic violence in Albania: A national population-based survey. Tirana: INSAT.

Haggard, S., and Kaufman, R. R., 1995. The political economy of democratic transitions. Princeton, NJ: Princeton University Press.

International Crisis Group, 1999, Jan 6. The state of Albania. Europe Report 54. INSTAT (Albanian Institute of Statistics). 2016. Tirana.

Jarvis, C., 2000. The rise and fall of Albania's pyramid schemes. Finance and Development, 1: 46-49.

Johnson, A. M., 2001. Albania's relations with the EU: on the road to Europe? Journal of Southern Europe and the Balkans, 2: 171-192.

Kadare, I., 2000. Lulet e ftohta te marsit. Tirana: Onufri.

Kadare, I., 2005. Shqiptarët në kërkim të një fati të ri. Tirana: Onufri.

Kajsiu, B., 2010. Down with politics!: The crisis of representation in postcommunist Albania. East European Politics \& Societies 24(2): 229-253. 
Kakwenzire, J., and Kamukama, D., 2000. The development and consolidation of extremist forces in Rwanda. In: Adelman, H., and Suhrke, A., eds., The path of a genocide: the Rwanda crisis from Uganda to Zaire. New Brunswick, NJ: Transaction Publishers.

Kaplan, R., 1994. The Coming Anarchy. The Atlantic, February 1994.

Krasniqi, A., 2014. Albanian transition, the contrast between eastern mentality and European identity. Interdisplinary Journal of Research and Development, 1: 62-66.

Levitsky, S., and Way, L. A., 2002. The rise of competitive authoritarianism. Journal of Democracy, 2: 51-66.

Levitsky, S., and Way, L. A., 2010. Competitive authoritarianism: hybrid regimes after the cold war. Cambridge: Cambridge University Press.

Mansfield, E., and Snyder, J., 1995. Democratization and the danger of war. International Security, 20: 5-38.

Marshall, M. G., and Cole, B. R., 2014. Global report 2014: Conflict, governance, and state fragility. Center for Systemic Peace.

Muco, M., 1997. Economic transition in Albania: political constraints and mentality barriers. Brussels: NATO.

Nicholson, B., 1999. The beginning of the end of a rebellion: southern Albania, May-June 1997. East European Politics and Societies, 13: 543-565.

Sadiraj, K., 1999. Albania: Transition to a Market Economy. Tinbergen Institute Research Series, no. 202, Amsterdam: University of Amsterdam.

Sambanis, N., and Hegre, H., 2006. Sensitivity analysis of empirical results on civil war onset. The Journal of Conflict Resolution, 4: 508-35.

Schmidt, F., 2002. Conspiracy theories in Albanian politics and media. In: Schwandner-Sievers, S., and Fischer, B. J., eds., Albanian identities: myth and history. London: Hurst and Company.

Snyder, J., 2000. From voting to violence: democratization and nationalist conflict. New York: W.W. Norton.

Stefani, A., 2005. Albanistan. Tirana: Botimet Toena. 
Trading Economics, 2017. Albania Unemployment Rate 1993-2017.

Vaknin, S., 2009. Macedonia: a nation at a crossroads. Skopje: Narcissus Publications.

Vickers, M., 1998. Between Serb and Albanian: a history of Kosovo. New York: Columbia University Press.

Vickers, M., 1999. The Albanians: a modern history. London: I. B. Tauris.

Vickers, M., 2008. The role of Albania in the Balkan region. In: Batt, J., ed., Is there an Albanian question?, Chaillot Paper 107. Paris: Institute for Security Studies.

Vickers, M., and Pettifer, J., 2007. Çështja Shqiptare, Riformësimi i Ballkanit. Tirana: Bota Shqiptare.

World Bank, 2015. Support to extractive industries transparency - Albania. Washington DC.

Yusufi, I., 2003. Security sector reform in south east Europe. Budapest: Centre for Policy Studies.

Yusufi I., Mara, I., Narazani, E., Stojilovska, A., Zuber, S., and Joshevska, J., 2012. Context analysis: migration and remittances and their impact in Albania and Macedonia. Skopje: Analytica/Regional Research Promotion Programme.

Islam Jusufi (ijusufi@epoka.edu.al) is a Lecturer and Head of the Department of Political Sciences and International Relations at Epoka University, in Tirana, Albania. His research interests relate to democratization processes and security politics in the Balkans. He earned his PhD in Politics at the University of Sheffield and did the bachelor and master studies in International Relations at the Universities of Ankara, Bilkent and Amsterdam. He served as a policy adviser on foreign security policy and on development cooperation. He held research and teaching fellowships at the Wilson Centre, Washington DC; the EU Institute for Security Studies, Paris; the ERSTE Stiftung, Vienna; UNESCO, Paris; the Centre for Policy Studies, Budapest; and NATO, Brussels. 